\title{
Drug User Behavior about the Development and Rehabilitation Process in Banda Aceh Correctional Institution
}

\author{
T. Alamsyah \\ Health Polytechnic, Ministry of Health, Banda Aceh, Indonesia \\ Corresponding author email: aalams@hotmail.com \\ Dewi Marianthi \\ Health Polytechnic, Ministry of Health, Banda Aceh, Indonesia \\ Wirda Hayati \\ Health Polytechnic, Ministry of Health, Banda Aceh, Indonesia \\ Nora Usrina \\ Health Polytechnic, Ministry of Health, Banda Aceh, Indonesia
}

\begin{abstract}
Narcotics prisoners are the focus of attention, where narcotics convicts need a more comprehensive and sustainable development, apart from being said to be law offenders. The purpose is to identify the implementation of rehabilitation of drug abuse cases in the correctional Qualitative research design with a phenomenological approach, through interview techniques (interview), observation, and documentation to 9 informants, namely cases of drug users in prisons. Researchers collect data concerning concepts, opinions, attitudes, and knowledge attitudes and actions of assessment and giving meaning to situations or experiences in life. The results of the research from the interviews show that the results of knowledge and attitudes and actions of the prisoners towards rehabilitation are very good and are still able to explain and accept changes from the rehabilitation program. Knowledge of attitudes and actions that are already good and able to follow the programs that have been determined to be implemented in the prison in Banda Aceh.
\end{abstract}

Keywords---behavior, drug, narcotics convicts, narcotics prisoners, rehabilitation.

\section{Introduction}

Correctional institutions are the final stage of the criminal justice system, the correctional institution itself has an important role because the institution is the best place for punishment guidance for those found guilty by a court decision (Riky Novarizal, 2013) Law Number 12 of 1995 concerning Corrections, article 1 number 3, which reads "Penitentiary, hereinafter referred to as LAPAS, is a place to carry out the development of prisoners and correctional protege. Then in article 1 point 2, it is written "The Correctional System is an arrangement regarding the direction and boundaries and methods of guidance (Victorio H. Situmorang, 2019). Narcotics prisoners are the focus of attention, where narcotics convicts need a more comprehensive and sustainable development, apart from being said to be lawbreakers. In coaching narcotic abuse prisoners, namely by providing therapy and training programs, namely: 1) Therapy Program for Drug Addiction which consists of a) Medical Rehabilitation Phase, namely in the form of Methadone Maintenance Program, Complementary Therapy. b) Non-Medical Rehabilitation Stage which consists of Therapeutic Community (TC) and Criminon. 2) After Care (Education) Rehabilitation Stages which include Integrated Islamic Boarding School activities (Putra, 2019). It is estimated that the number of drug abusers in Indonesia is 3.8 million to 4.1 million people or around $2.10 \%$ to $2.25 \%$ of the total population of Indonesia who are at risk of being exposed to drugs in 2014. This has increased when compared to 2008, namely $1.9 \%$ (BNN, 2017). 
The National Narcotics Agency (BNN) together with 1,593 large rehabilitation centers managed by BNN have implemented rehabilitation programs for 38,427 narcotics abusers throughout Indonesia. This figure has increased, wherein the previous year only around 1,123 addicts and abusers were rehabilitated (BNN, 2017). Aceh Province, said Farid, occupies the sixth position in Indonesia with estimated drug users of 56.192 or 1.90 percent. While the types of drugs used were cannabis 65.5 percent, crystal methamphetamine 38 percent, and ecstasy 18 percent. "The age at the first time to use drugs is 17 to 19 years. Most drug users are in the productive age between 35 and 44 years,"

Drug rehabilitation is a general term for the process of medical treatment and/or psychotherapy, for dependence on psychoactive substances such as alcohol, prescription drugs, and street drugs such as cocaine, heroin, or amphetamines. The clear intention is to enable patients to reduce previous levels of abuse, to avoid the psychological, legal, social, and physical consequences of extreme abuse (Stanis \& Andersen, 2014). Rehabilitation based on therapeutic communities has a special characteristic, namely intending to be able to return drug addicts to socializing well in the community and at the same time facilitating control (Safitri et al., 2016). Observing the development of narcotics abuse and illicit traffic lately, it has reached an alarming situation, so it becomes an urgent issue. Victims of narcotics abuse are not only adults, students but also high school students to elementary school students. Adolescents are one of the groups that are vulnerable to narcotics abuse because, in addition to being dynamic, energetic, they are always curious. They are also easily discouraged and easily influenced by traffickers, which results in drug abuse problems (Health, 2015). Drug abuse is a public health problem worldwide (Tang \& Orwin, 2009).

\section{Material and Methods}

This study uses a qualitative design with a phenomenological approach. to explore the behavior (knowledge, attitudes, and actions) of cases of drug users during the rehabilitation period in correctional institutions (Alamsyah et al., 2020). Data collection techniques through in-depth interviews and observations (Chu \&Chang, 2017). The subjects involved were 9 Respondentondents. This research was carried out in correctional institutions in Aceh for six months. The qualitative research instrument is the researcher himself with tools, namely a letter of consent to become a respondent demographic data, FGD guidelines, interview guides, and observation guides. During the FGD, in-depth interviews, and observations, researchers were also assisted by note-takers and observers. The tools that will be needed at the time of implementation are a camcorder as an image recording device and a cellphone voice memo as a voice recorder.

\section{Result}

The results of qualitative analysis on 9 participants found that there were eight subcategories from many meaning units. From the eight sub-categories, three categories were formed following the research objectives. The purpose of this study is knowledge about drugs, attitudes towards drug abuse, and the actions taken during drug rehabilitation at the level 2 prison in Banda Aceh. themes, categories, and sub-categories can be seen in Table 1 below.

Table 1

Themes, categories, and sub-categories based on the results of the analysis on drug users at the Banda Aceh Penitentiary

Themes, Categories, and Sub-Categories Table 1.

Drugs are dangerous goods that harm the human body with the impact that they can go to prison

Category Knowledge about drugs

\begin{tabular}{ll}
\hline Sub-category & Definition of drugs \\
\hline Sub-category & Causes of drug abuse \\
\hline Sub-category & Impact of drug abuse \\
\hline
\end{tabular}


Table 2

Various reasons people abuse drugs with the effects and impacts that are felt are different from one another

\begin{tabular}{ll}
\hline category & Attitudeof drug abuse \\
\hline Sub-categories & of drugs used type \\
\hline Sub-category & Reasons drug abuse \\
\hline Sub-category & effect felt when using the drug \\
\hline sub-category & level of dependence \\
\hline Sub-category & Hope after leaving \\
\hline
\end{tabular}

Table 3

Various activities were conducted for prisoners coaching therapy does not focus on drug cases

\begin{tabular}{ll}
\hline category & Program for prisoners in prison, \\
\hline Sub-category & Definition of guidance, \\
\hline Sub-category & Type of guidance, \\
\hline Sub-category, & Criteria for guidance, \\
\hline Sub-category, & Coaching activity, \\
\hline Sub-category, & the effectiveness of coaching, \\
\hline $\begin{array}{l}\text { Sub-category } \\
\text { guidance }\end{array}$ & Hope for
\end{tabular}

\section{Discussion}

Drug abuse itself is one of the most complex problems in Indonesia today. Drug abuse can occur in all age groups, including children, adolescents, adults, and the elderly. Drug abuse itself cannot be separated from the knowledge, attitudes, and actions of a person who cannot be controlled due to very complex driving factors, such as divorce from parents, relationships, even the desire to experiment to find out what effects drugs have.

\section{Knowledge of Drug Users}

Based on the results of interviews about the knowledge that in general, drug users can find out that drugs or narcotics are dangerous substances and can cause dependence to disturb the future, but this is done because of the stress of not being able to sleep and not having friends. But initially influenced by friends in the association. The informants 'knowledge about drugs was only obtained from the informants' friends who said that drugs were not dangerous and could make the mind and body fresher. Meanwhile, the informants' knowledge of what drug abuse is according to them is the use and distribution of illegal drugs. Informants know the dangers and impacts of drug abuse after being caught in a narcotics case and becoming a prisoner by undergoing rehabilitation carried out by the Penitentiary.

\section{a. Definition of Drugs}

"Respondent 1, drugs are dangerous goods and deadly drugs

Respondent 2, drugs are illegal drugs that can make users go to 
jail"

b. Cause of Drugs

"Respondent 3, I know drugs from friends, so I joined in, the beginning of the smoking habit I continue to want to try something else.

Respondent 1, I just go along with the environment, because I am a driver so we are used to using it. "The

c. the effect after using drugs

" Respondent 4, actually everything becomes disturbed, especially the family is ostracized by the environment and All the neighbors

Respondent 6, I became sleep-deprived, dizzy, only my appetite increased, so I became gender qi, Respondent 9. Yes after I was arrested my future was lost, I could not go to college anymore "and carry out the punishment

Knowledge is a factor of drug abuse, where knowledge will influence what action he will take. In research conducted by Wishesa, it was found that there was a significant relationship between the level of knowledge and drug abuse (Sholihah, 2015). In a limited number of studies examining users' knowledge of drugs and all of the studies discussed here have only made limited attempts to assess knowledge, future research should begin to examine actual knowledge rather than perceived knowledge (Leeds Metropolitan University, 2007). Based on the results of the Home Office Online Report. The main predictors of drug use are parental discipline, family cohesion, and parental monitoring. Several aspects of the family structure such as large family size and low parental age are associated with adolescent drug use (Bloor \& Hickman 2007). According to the Triple R report: Rehabilitation For Recovery And Reinsertion for knowledge and thought materials for practitioners in the field of addiction and for policymakers and related stakeholders interested in recovery-oriented models of rehabilitation and about the importance of investing in recovery as strong and long-term social skills. returns for individuals, families, and communities (Molina-Fernandez, 2017).

Hassan Lone's research results revealed that although $87.33 \%$ of respondents were aware of the drug addiction process, $92.67 \%$ of respondents did not know about the drug addiction/treatment center that was run in the city of Srinagar. Only 3.33\% of respondents know about NGOs working in the field of drug addiction in the city of Srinagar (Lone \& Mircha 2013) moderate According to Carmel, this is achieved by examining the experiences of those who have participated in secondary treatment programs. This report focuses specifically on the secondary care Fellowship House and Renewal program. These programs are developed and delivered by Tabor Lodge Treatment and Addiction Services Limited. This study uses two main research strategies to evaluate the schema; (1) primary qualitative research collected through semi-structured interviews with subject matter experts and (2) publishing research on addiction treatment and its effectiveness (Brien et al., 2014).

Following the theory put forward by Lawrence Green regarding behavior, (Kassaye et al. 2017) where a person's health is determined by 2 main factors, namely behavioral causes and non-behavior causes. Furthermore, this behavior is formed from several factors, namely predisposing factors which are manifested in knowledge, attitudes, actions, then enabling factors that are manifested in the available facilities or means, as well as reinforcing factors that are realized. in the attitudes and behavior of health workers or other workers. According to Hillary's research, using more than one drug method or preparation is common. Reasons for use include arthritis, chronic back pain, anxiety, and depression (Suhron, 2018; 2020; Suhron, 2017; 2016). Marijuana users last year reported improvements in overall health, quality of life, daily functioning, and increased pain (Lum et al., 2019).

\section{Attitudes of Drug Users}

From the results of interviews conducted, the cause of informants abusing drugs on average started with family problems. , then stress because of work, so that they consciously and driven by their desires to associate with fellow drug users and use these drugs, then after they use drugs they think that they feel more enthusiastic at work 2. Attitude.

"Respondent 2. Indeed, the types of drugs are different sir, so the effect you feel also depends on the type of drugs we use. such as marijuana and drugs and methamphetamine

Respondent 3. I use drugs depending on the situation sir because when I was invited My friend, I just joined in at first but gradually became dependent.

Sep 8, I want to repent, sir, I will not repeat it, I want to organize my life for the better," 
Following the theory put forward by Lawrence Green regarding behavior, where a person's health is determined by 2 main factors, namely the behavior factor. causes) and factors outside of behavior (non-behavior causes). Furthermore, this behavior is formed from several factors, namely predisposing factors which are manifested in knowledge, attitudes, actions, then enabling factors that are manifested in the available facilities or means, as well as reinforcing factors that are realized. in the attitudes and behavior of health workers or other workers. Rehabilitation as an effort to dependent narcotics addicts certainly has many advantages, apart from the focus on the purpose of criminal narcotics crime convictions, where rehabilitation can be used as an alternative way so that correctional institutions that are deemed no longer able to accommodate prisoners can be included in the Rehabilitation Institution. Rehabilitation is considered effective in solving problems related to the abuse and trafficking of narcotics in Indonesia (BNN RI, 2009). Based on the results, Chamberlin's research shows that prisoners have changed substantially over the past decade, with needs concentrated in a small proportion of prisoners. As a result, correctional institutions are not always able to match offenders with appropriate services, which may have a direct impact on institutional safety (Chamberlain, 2012) reports finding that residents with a personal or family history of drug use have higher positive attitudes towards patients with addiction, and also a better trend towards harm reduction policies (Barral \& Eiroa-Orosa, 2015).

Meanwhile, according to Layla Alhyas, many factors are believed to increase the risk of substance use among adolescents such as peer pressure, insufficient knowledge about the consequences of drug use, family-related factors (eg low monitoring and poor parent-adolescent relationships), affordability, and availability of substances, boredom, and affluence (Alhyas et al., 2015). The 2006 Survey of Health Behaviors in School Children found that overall the percentage of children who reported having consumed marijuana in the last 12 months was relatively stable between $2002(11.1 \%)$ and $2006(11.3 \%)$. The percentage remained stable among boys and girls a slight increase was seen among the 12-14 age group (4.8\% to $6.7 \%)$. However, there was also a marked decrease among boys aged $15-17$ from $30.5 \%$ to $24.6 \%$ (Monaghan \& Mc Grory, 2008).

\section{Actions of drug users}

Human actions or behavior are all human activities or activities, either which can be observed directly or that cannot be observed from the outside. Action is an activity or activity of humans/individuals in respondents to external stimuli received by the individual concerned. Human behavior is human action or activity, for example, walking, talking, crying, laughing, working, studying, writing, reading, and so on. In the process of formation and change, behavior is influenced by several factors, including internal factors and external factors as mentioned above (Afianty, 2014). The prevention system for handling narcotics crimes is also called continuous rehabilitation. Namely a system that contains components of early admission, rehabilitation, post-rehabilitation, and termination. The working mechanism in this system is in the form of system input consisting of addicts, abusers, and victims of narcotics abuse.

Also, a set of assessment tools, both medical and psychological. Proceed through four stages of intervention. The system output is in the form of former clients/addicts/narcotics users who have recovered and returned to life in a productive society. Thus narcotics clients do not experience dependence on narcotics so that demand reduction as one of the strategies to eradicate narcotics is successful. In other words, there is no more demand for drugs because addicts have recovered (Putra \& Djauhari 2017). From the informants' statements through the In-depth Interview method conducted, the impact they felt while using these drugs was different, namely "3. Actions

\section{"Respondent7, so far I am very serious about just following the activities in this Penitentiary. \\ Respondent8, I am now focusing on activities that are positive such as prayer and recitation at any time, at least from here I can recite the Koran "following all the orders of Allah SWT.}

From the results of observations, the actions of prisoners while in detention, some prisoners experience various Behavioral disorders before or after rehabilitation, for example, being easily stressed, being temperamental to other prisoners when there is a conflict, more easily frightened, and even being quiet, speaking styles that are not understood by other prisoners, when asked questions, the answers are not following what is being asked (Afianty, 2014). The results of the study showed that there was a significant difference between the coping mechanism of the client's drug rehabilitation client before and after supportive therapy $(P=0.0001)$ and there was no significant 
difference in the coping mechanism of the drug rehabilitation client's family between psycho-educative therapy and supportive therapy. $(\mathrm{P}=0.094)$. Family drug rehabilitation patients, both in the psycho-educational group and in group supportive therapy, are advised to continue to support and coordinate group therapy activities so that they will increase their understanding and willingness to be able to solve their problems together (Alamsyah. $\mathrm{T}$ et al, 2019). The next activity is congregational prayer. Prayers in the congregation are not forced on drug addicts, because the effects of drugs in their bodies bring negative changes in feelings, behavior, or thoughts. Then in reading the Qur'an, there are many benefits obtained by drug students in reading the Koran. One of them is drug addict patients who cannot read the Koran are better / better than before. The activity of reading the Koran is also interspersed with studying the interpretation of the verses of the Qur'an so that drug addicts can understand the contents of the verse. Thus patients with drug addicts will be motivated to learn more deeply about the Koran (Bakri \& Barmawi, 2017).

\section{Conclusion}

Prisoners' knowledge of cases of drug users at the Banda Aceh Prison, in general, drug users can know that drugs or narcotics are dangerous substances and can lead to dependence and can disrupt the future, but this is done because the stress is not biased. sleep as well as not friends. The attitude of drug users who are very respondents and able to follow the program that has been in is also able to apply or practice the things that are given in the Rehabilitation process established by the Banda Aceh penitentiary. while the act of human / individual activities or activities in respondents to external stimuli received by the individual concerned. Human behavior is a human act or activity.

\section{References}

Afianty, RD, Martioso, PS, \& Hadi, HT (2014). Description of Knowledge, Attitudes, and Behavior of Vocational High School Students "X" About Drugs in Bandung, 2014 (Publication Manuscript). Bandung: Faculty of Medicine, Maranatha Christian University .

Alamsyah, T., Candra, A., \& Marianthi, D. The Pageu Gampong Model in Aceh Culture on Drug Handling. International Journal of Health Sciences, 4(3), 49-59.

Alamsyah, T., Usman, S., Marianthi, D., \& Syamsuddin, A. Use of Psycho-Educative and Supportive Therapies for Improving Coping Mechanisms of Families of Drug Rehabilitation Patients in Mental Hospital Banda Aceh.

Alhyas, L., Al Ozaibi, N., Elarabi, H., El-Kashef, A., Wanigaratne, S., Almarzouqi, A., ... \& Al Ghaferi, H. (2015). Adolescents' perception of substance use and factors influencing its use: a qualitative study in Abu Dhabi. Jrsm Open, 6(2), 2054270414567167. https://doi.org/10.1177/2054270414567167

Bakri, N., \& Barmawi, B. (2017). The Effectiveness of Rehabilitation of Narcotics Addicts Through Islamic Therapy at the National Narcotics Agency (BNN) Banda Aceh. Psychoislamedia: Journal of Psychology, 2 (1), 86-95. https://doi.org/10.22373/psikoislamedia.v2i1.1827

Barral, C., Eiroa-Orosa, F. J., Navarro-Marfisis, M. C., Roncero, C., \& Casas, M. (2015). Assessing knowledge and attitudes towards addictions in medical residents of a general hospital. Drugs: Education, Prevention and Policy, 22(6), 457-462. https://doi.org/10.3109/09687637.2014.987218

Bloor, R., \& Hickman, M. (2007). Predictive factors for illicit drug use among young people. Probation J, 54(3), 2017.

BNN RI. (2009). Law number 35 year 2009 concerning Narcotics (LN 2009/140, TLN 5059), 5 (1).

BNN. (2017). National survey of drug abuse in 34 provinces in 2017.

Chamberlain, A. W. (2012). Offender rehabilitation: Examining changes in inmate treatment characteristics, program participation, and institutional behavior. Justice Quarterly, 29(2), 183-228. https://doi.org/10.1080/07418825.2010.549833

Chu, PH. \& Chang, Y. (2017). John W, Creswell, Research Design: Qualitative, Quantitative, and Mixed Methods Approaches. Journal of Social and Administrative Sciences, 4 (June), 3-5.

Health, KR (2015). State Gazette of the Republic of Indonesia. Minister of Health of the Republic of Indonesia Regulation of the Minister of Health of the Republic of Indonesia, Number 65 (879), 2004-2006. https://doi.org/10.1093/bioinformatics/btk045

Leeds Metropolitan University. (2007). International Literature Review: Attitudes, Behaviors, Knowledge, and Education - Drugs in Sport: Past, Present, and Future, (January), 1-199. Retrieved from http://www.wadaama.org/rtecontent/document/backhouse_et_al_full_report.pdf

Liem, A. (2010). The Effectiveness of Anti-Drug Training. Research, 13 (2), 241-262.

Lone, G. H., \& Mircha, S. (2013). Drug addiction and the awareness regarding its possible treatment and rehabilitation of young drug users in Kashmir. International NGO Journal, 8(4), 80-85. 
Lum, C., Stoltz, M., Koper, C. S., \& Scherer, J. A. (2019). Research on body-worn cameras: What we know, what we need to know. Criminology \& public policy, 18(1), 93-118.

Molina-Fernández, E. (2017). A study of educational programmes that promote attitude change and values education in Spain. Asian Social Science, 13(7), 112-130.

Monaghan, L., \& Mc Grory, S. Development of a Parents' Resource Manual Booklet to equip parents/guardians to provide early and appropriate responses to young people's substance use.

Permensos. (2014). Regulation of the minister of sociality of the republic of indonesia number 08 year 2014 concerning. PMK Permensos, 53 (9), 1689-1699.

Prisaria, N., \& Suharto, S. (2012). The relationship between knowledge and the social environment on drug use prevention measures in SMA 1 Jepara students. Diponegoro Journal of Medicine , l (1), 104961.

Putra, RA (2017). The Role of Prisons in the Development of Narcotics Abuse Prisoners (Study in the Class Ii A Correctional Institution in Sragen). Journal of Chemical Information and Modeling, 53 (9), 1689-1699. https://doi.org/10.1017/CBO9781107415324.004

Riky Novarizal. (2013). Narcotics Institutions, 23.

Safitri, IW, Handajani, RP, \& Sujudwijono, N. (2016). A drug addict rehabilitation center based on a therapeutic community with a healing environment approach in Batu City. Journal of Architecture Department Students, 4 (2).

Sholihah, Q. (2015). The effectiveness of the p4gn program on prevention of drug abuse. Journal of Public Health, $11(1), 87-95$.

Stanis, J. J., \& Andersen, S. L. (2014). Reducing substance use during adolescence: a translational framework for prevention. Psychopharmacology, 231(8), 1437-1453. https://doi.org/10.1007/s00213-013-3393-1

Suhron M, A Yusuf, R Subarniati, F Amir, Z Zainiyah. How does forgiveness therapy versus emotion-focused therapy reduce violent behavior schizophrenia post restrain at East Java, Indonesia? 2020. International Journal of Public Health Science (IJPHS) 9 (4), 214-219

Suhron M, Zainiyah Z., How Were Stress Family and INSR (Insulin Receptor) Expression in Polycystic Ovary Syndrome (PCOS) Insulin Resistant in Madurese Tribe? : Indonesia. Systematic Reviews in Pharmacy. Vol 12 (1), pp. 170-175. 2020

Suhron M., Self-concept nursing care: Self-esteem / Self-concept nursing care: Self-esteem (Self-esteem nursing care), "Publisher, Ponorogo: Unmuh Ponorogo Press. 2016.

Suhron, F Amir. Reduce violent behavior schizophrenia: A new approach using LT (Laughing therapy) and DRT (Deep relaxation therapy). Indian Journal of Public Health Research \& Development. 2018: 9 (8): 1518-1523

Suhron, M, A Yusuf, R Subarniati. Assessment of Stress Reactions and Identification of Family Experiences in Primary Care Post Restrain Schizophrenia in East Java Indonesia. Mix Method: Sequential Explanatory. Indian Journal of Public Health Research \& Development. 2018; 10 (12): 1849-1854.

Suhron, M. "Self-esteem concept of mental nursing care / Care of Mental Nursing The concept of self-esteem". Jakarta: Mitra Wacana Media; 2017

Suhron, M. Model of Potential Strengthening and Family Roles in Improving Family Members for ODGJ Adaptability http://conference.unair.ac.id/index.php/isoph/isoph/paper/view/1147. Publication Name: proceeding of The 2nd International Symposium of Public Health. 2018; 1 (1): 344-354

Tang, Z., \& Orwin, RG (2009). Marijuana initiation among American youth and its risks as dynamic processes: prospective findings from a national longitudinal study. Substance Use \& Misuse, 44 (2), 195-211. https://doi.org/10.1080/10826080802347636

Victorio H. Situmorang. (2019). Correctional Institution as Part of Law Enforcement Abstract, 85-98. https://mediaindonesia.com/nusantara/388577/tren-penylasi-narkoba-di-banda-aceh-men

Yusuf, Ah., Rika, S., Suhron, M., "Assessment of the Kempe Family Stress Inventory in self-care post-restrain schizophrenia," International Journal of Public Health Science (IJPHS), vol. 8, no. 2, pp. 55-59, 2019

Zainiyah Z, Suhron M, Psychological Detection Of Stress And Shbg (Sex Hormone Binding Globulin) In Insulin Resistant Of Polycystic Ovarium Syndrome (Pcos) In Women, Indonesia. SRP. 2020; 11 (11): 1875-1880. 